\title{
Yom Kippur Eve
}

\author{
September 26, 1982
}

When Rabbi Beerman took the pulpit on the eve of Yom Kippur in 1982, it was barely a week after the massacre of hundreds (and perhaps thousands) of Palestinian refugees by Christian Phalangist militia men in the Sabra and Shatila camps in Beirut on September 16-18. The Phalangists were operating in the camps under the general command of Israeli forces that had taken control of Beirut as a result of intense fighting in the summer of 1982.

Beerman did not miss the opportunity to peer into his soul and that of his fellow Jews, to engage in the work of heshbon ha-nefesh (moral accounting) that Jewish tradition encourages on Yom Kippur. The day, he declared, "has always been a call to conscience." And he, as the spiritual shepherd of his well-heeled congregation, felt a particular obligation to issue and answer that call.

Beerman numbered himself among the few American Jews-and surely rabbisto deem the first Lebanon War "a moral and political failure" from its first day. He lamented the fact that virtually every national Jewish organization lined up in unwavering support of the decision of the Israeli government to invade Lebanon. And yet, the Lebanon War proved to be enormously divisive. In Israel, it was called the first war to lack a national consensus and prompted widespread protest by antiwar activists. Abroad, the early stages of the war began to create "troubled consciences" among Diaspora Jews, as the New York Times reported. ${ }^{1}$

For Beerman, the Lebanon War represented a gross violation of the prophetic impulse to seek out justice and righteousness. It was a case in which the once powerless not only had become powerful, but were also corrupted by the power they assumed. The scale of destruction wrought by the Israeli invasion was vast and was the result of "arrogance and self-destructive impulses." The hour demanded a new 
"declaration of independence" for Diaspora Jews, who must unmoor themselves from silent complicity, assert their consciences, and embark on the path of repentance that Yom Kippur demanded.

These are the words we read in our service every Rosh Hashanah morning, the words of Paul Kornfeld, born 1889 in Prague, died in Lodz concentration camp, 1942:

Everything on this earth follows the age-old rules.

When spring comes, the ice melts ...

And when someone is enraged he does evil.

Yet no rule or law can keep us from dreaming

that one day all this travail will turn to ashes, and that You, oh my Lord, playful and senseless, great and powerful,

will cause a new rule to blossom forth under your breath, and the miracle will spread across the earth.

How glorious it would be, were Your will written throughout the world through Your deeds.

See! - the world is a dark pit, and men haltingly stumble and falter from abyss to abyss, from battle to battle...

They aim for the good and commit the evil, they do evil and regret it...

They think about what they have wrought and tear their own flesh.

And they are full of errors and full of lies....

And everything has its reason and its cause.

Also the evil has its cause...

Also the lie has its cause...

And the errors have their cause.

And everything goes its way according to the age-old

rules and laws...

Last week, at the close of the service on Rosh Hashanah eve, as Rabbi Ragins, Cantor Sharlin, and I stood wishing members of the congregation a good year, one of our members, a veteran of many differences with me over the many years of our friendship, greeted me warmly and said, somewhat impishly: "I'm so grateful you didn't speak about the war in Lebanon tonight, and that you will be addressing that subject on Yom Kippur. Because I won't be here on Yom Kippur; I'll be on my way to India."

Oh, I wish I might be with him tonight, wherever he is, and I have colleagues throughout the land who feel the same. Their hearts are heavy, full of anguish, and yet they know, as I do, that it is their responsibility to attempt to provide some 
guidance, some understanding of the events that have shaken the conscience of every Jew. And what is a more appropriate time for this than the Day of Atonement?

Yom Kippur has always been a call to conscience. It has always urged us to acknowledge a simple truth-that we are human, and therefore subject to error, transgression; that by our deeds of omission or commission we may have added to the store of indecency in the world. Yom Kippur tells us that we should turn away from the way we have been going and choose another way, a way of justice and love, a way that leads to our fellow human beings. The sins we confess this day are meant to encompass every domain of our lives, the personal and the collective, wherever we have negated by word or deed the ideals we cherish. Yes, Yom Kippur is a call to conscience, an annual reminder of the distance that separates our ideals from our conduct. Yom Kippur is a celebration, a celebration of moral failure.

We all shrink from this responsibility. It implies, with Cassius, that the fault is not in our stars but in ourselves, that we are not the persons we pretend to be or wish to be. In Judaism, Leo Baeck once taught us, the highest possible standard is imposed upon us. "The ethical command with its ceaseless, thou shalt, stands before us and demands our life. Our ethical consciousness is the consciousness of an unending task. If we can feel a reverence toward this task, then we can feel a reverence toward ourselves."

So we are challenged not to blunt the conscience but to awaken it. Not to pretensions of virtue, but to the acknowledgment of moral failure.

The contemporary rabbi who ventures to lead his congregation up this path is aware that he is engaged in a dangerous mission. For the rabbi is the bearer of a dark secret. He knows he is the servant of a religion which rarely developed any passion for the dilemmas of the privileged. The calf worshippers of old, who stood at the foot of Sinai, sincerely believed that they were worshipping the God of Israel.

The rabbi who serves a congregation as fashionable and respectable as this one feels too often like an Aaron, the brother of Moses, who took the gold, fashioned the calf, and gave the people exactly what they wanted. The rabbi who serves the enlightened and the affluent knows that he is the bearer of a religious tradition whose God pants after the disinherited, the lonely, the abandoned, the homeless. Its God is the god of the hunted, not the hunter; of the defeated, not the victor.

How does the teacher, the rabbi, how does any knowledgeable Jew, take this tradition with its literature of tragedy and loneliness and the joy that flowers from it, how does one take a religion of the insulted and the injured, and guide his congregation on the path that leads to the acknowledgment of moral failure, the awakening of conscience, the path that leads to the repentance that this day calls for?

I do not know that I can do it. I certainly cannot do it alone. I need your help, as never before.

Everything has its reason and its cause Also the evil has its cause 
Also the lie has its cause

And everything goes its way according to

the age-old rules...

I confess to you: I am one of that minority of rabbis, and that minority of Jews here and in Israel who believed, from the first day, that the war in Lebanon, the war of Begin and Sharon, was doomed to be a moral and political failure. I confess to you, I was full of shame and horror and despair from the very first moment of the Israeli invasion of the Lebanese border. And yet I prayed that I was wrong. I prayed that some blessing might be wrested from the destruction and the loss of life this invasion, or, as Menachem Begin insists on calling it, this "incursion," might bring.

I listened to the news with dread. I read every piece of information, particularly those issued by the major Jewish organizations: ADL, the AJC, the CRC, the Federation Council, which without exception celebrated and justified the Israeli action. Then I began to see some of the material from the Israeli press. There was that story of Col. Eli Geva, an armored brigade commander who created a sensation in Israel by asking to be relieved from his command rather than lead an assault on Beirut. The Israeli newspapers reported an exchange between Prime Minister Begin and Col. Geva. Begin, who hoped to persuade the young colonel to change his mind, asked why the colonel, the youngest brigade commander in Israeli history, wanted to be relieved of his command. Geva replied that when he looked through his binoculars into West Beirut he could see children playing. "Did you receive an order to kill the children?" Begin asked him. "No," Geva replied. "Then what are you complaining about?" the Prime Minister is reported to have said.

Then there was Mattityahu Shmuelevitz, Director General of the Prime Minister's office, who told the following story: "Three men, one an Israeli, are captured by cannibals, and while the cauldron of water is heating they are each granted a final wish. After the others' conventional wishes are met, the Israeli makes his request-that the cannibal chieftain kick him in the behind. The wish fulfilled, the Israeli pulls his Uzi sub- machine gun from under his shirt, kills his tormentors and sets his companions free. 'But why did you ask him to kick you?' they asked. 'Because, otherwise, no matter how justified my shooting him, I will still be accused of aggression,' the Israeli replied. So we take into account that we shall be accused of aggression even when the water to cook us is already boiling," said Mr. Shmuelevitz, as he launched into his analysis of negative world reaction to the Israeli invasion.

Eliyahu Ben Elissar, Israel's first ambassador to Egypt, and now chairman of the Foreign Affairs and Defense Committee of the Knesset, Israel's parliament, explained international hostility in these terms: "The free Christian world has still a long way to go to get used to a new type of Jew," he said. "We are a very normal people. No nation would allow its citizens to be killed with impunity, but 
somehow, people take it for granted that Jews have always been killed throughout their history. While Americans or French or others would never let it happen, we have always been asked to behave otherwise. But we are not the Jews of the Diaspora. We will show the nations that we are not that kind of Jew."

Statement by Robert Alter, distinguished professor at the University of California, Berkeley, from an old issue of COMMENTARY in the bottom of my desk drawer, to be taken out whenever I become too moralistic: "Morality on the subject of Israel comes cheap to an American Jew, because he is not directly confronted with the responsibilities of power, the naked needs of survival ..."

Letter to the Editor of the American Jewish periodical SHMA: "God bless our Jewish intellectual liberals [the rabbis among them]. God bless them with their Jewish consciences and their Jewish sympathy for the hurt and suffering of all people. God bless them and keep them far from positions of responsibility. We need their prophetic reminders of who we are and how we should act, but we would have disappeared off the face of the earth many generations ago if we had let them make the practical decisions of daily existence."

From the Israeli newspapers: Israeli actress Hannah Meron, whose leg was blown off several years ago by a PLO terrorist bomb, speaking at a rally in Jerusalem, said: "I met two wounded Lebanese children. Both had their legs amputated. I came to cheer them up. I do not have to tell you how hard it was for me to look into their eyes. For the first time in my life I feel that I am an accomplice to an act with which my conscience cannot live."

Zion will be redeemed with justice.

I will break the bow and the sword and the battle out of the land ...

They shall beat their swords into plowshares ...

Everything has its reason and its cause

And everything goes its way according to the age-old rules and laws.

The stated purpose of the war: To secure peace for the Galilee. Prime Minister Begin solemnly promised that "when we reach the 40 kilometer limit the fighting will cease." It soon became clear that that was a lie. It should have been obvious. It was well known to Israeli military correspondents that Israel had been looking for a pretext to push itself into a full-scale war in Lebanon in order to liquidate once and for all the PLO, thus securing Israel's northern border and bringing to submission the Palestinian population of the occupied West Bank and Gaza, having deprived them of their national leadership.

The purpose of the war: To destroy the PLO, but in truth, if anything may have been destroyed it is the moral stature of the State of Israel. The massive use of military force, including the total destruction of refugee camps, not only caused death and destruction for the civilian population; it also supplied credibility to the hostile propaganda that presents Israel as an aggressive state, bent on expansion 
and annexation, while trampling on the rights of the Palestinian people. It permitted every closet anti-Semite to come out into the open.

The purpose of the war: To destroy the PLO. It may have been destroyed as a military force, but the war of Begin and Sharon achieved the very opposite of destroying the PLO: It has raised the PLO to a more important factor in international relations and has made the Palestinian issue the decisive one. The Pope would never have received Yasir Arafat had it not been for this war. Yes, the PLO's brutality is well known. Yes, its deeds of terror have brought death to the innocent, but "it never constituted a threat to Israeli security," Abba Eban declared. "This war," Eban said, "has been a dark age in the moral history of the Jewish people."

To "crush" the PLO, to "eradicate," to "liquidate," to "fumigate," to "wipe out," this was the new Jewish lexicon of Menachem Begin. And as he said in a June letter to President Reagan, "we are marching to Berlin to liquidate Hitler."

Jews who were opposed to this war were not complete fools or zealots or ideologues. We knew how much the people of Lebanon had suffered from the presence of the PLO in their midst, and the tremendous loss of life, greater than under the Israeli invasion. We were fully cognizant of the PLO's tactics, its politics of negation: NO, to the State of Israel; NO, to the Sadat initiative; NO, to the Israeli peace forces which had sought dialogue with them. The stubborn, rigid, reckless, brutal policies of the PLO betrayed the possibilities of a just solution for both Israelis and the Palestinian people. Yet the suffering of the Palestinians is sorrowful and painful and real. The terrible blunders of the PLO did not diminish the hope that something constructive might emerge from their midst; that they might create a leadership that would be able to respond positively.

For the PLO was the leadership of the Palestinian people; it was a bad leadership but a leadership nonetheless. It was a leadership that should have been dealt with, with selective military force but also (as A. B. Yehoshua said) "by reasonable and honorable proposals that would have challenged it to change its stand, alternatives whose moral test would lie in the fact that Israelis would be able to say in all honesty that if they were in the position of the Palestinians, they would be prepared to accept this as a final compromise proposal."

This was not the path chosen by successive Israeli governments, culminating in the excrescence of this one. So while Israeli soldiers fell in the Lebanese war and their obituaries appeared in the Israeli newspapers, there appeared continuously advertisements for housing on the West Bank at extremely low prices seeking to attract more and more Jews to the area.

The war has been fought. The dead have died, and the latest massacre adds to the toll. The Israeli radio report of the provisional estimate of the losses: 340 Israeli soldiers dead; 2,078 wounded. 17,000 Lebanese Palestinians killed; 30,000 wounded. About 50,000 people altogether, not to mention the 100,000? 200,000? 300,000 ? homeless. What kinds of Jews are these who kill and injure so many thousands and cause such massive destruction as a reasonable technique for carrying 
out policy? As the defeated Palestinians strengthen their national will by weaving heroic tales and creating a new martyrology, thousands upon thousands of Israeli citizens (over 300,000 of them) and Jews throughout the world are expressing their shock and shame-a tribute to the true Jewish spirit, a clear demonstration that it still breathes. ${ }^{2}$

The Israeli government cannot end the Palestinian will for nationhood. Will the world permit another wandering people to be driven forth with no place to go? We Jews are the one people of the world who should have known what it was like to be unwanted, to be homeless. No one wanted Jews-not America, not Britain, not Europe-there was only one place to go, and that was home, and Israel came into being for that purpose. There is one, one place for the Palestinians to go-homeand it is time long overdue for Israel to declare that it does not wish to rule over the Palestinian people and to annex their territories, that it is ready to negotiate with them on their right to self-determination and independence, if they in turn will give up the option of military struggle.

Thus far, not one Israeli government - not the labor governments of Golda Meir, Rabin, nor that of Menachem Begin-not one of them has been willing to make this declaration. There is no hope for Israel—no hope for peace in the Middle East unless this offer is at least attempted, and unless this reality is confronted.

"I, the Lord, will put my law within them: I will write it upon their hearts: and I will be their God and they will be My people," said the prophet Jeremiah.

"Your hands are full of blood, your fingers with guilt. Your lips have spoken lies, and your tongues mutter wicked things. No one calls for justice, no one pleads his case with integrity. They rely on empty arguments and speak lies, and your tongues mutter wicked things. No one calls for justice, no one pleads his case with integrity. They rely on empty arguments and speak lies: they conceive trouble and give birth to evil . . . acts of violence are in their hands . . . they are swift to shed innocent blood. The way of peace they do not know: there is no justice in their paths," said the prophet Isaiah.

Let us choose Jeremiah, not Begin and Sharon (as my friend Rabbi Jerome Grollman has said). ${ }^{3}$

Let us choose Isaiah, not any of the governments of Israel.

This is not the first time in Jewish history that our people has succumbed to arrogance and self-destructive impulses. In the least fertile periods of Jewish history, the vehemence of religious feeling and mystical pretensions of power led to excesses of Jewish dogmatism and fanaticism and the betrayal of all that lay at the center of the moral purpose and vision of our religious civilization. The Bible records it in shame. Thus Israel fell to the Assyrians. Judah was destroyed by the Babylonians. The descendants of the Maccabees became corrupt and ruthless with power, and Israel's independence was taken away. A band of mystical religious zealots thought that they could take on the mighty armies of Rome in the second century. Israel was destroyed, a million and a half Jews were killed, and in some 
incomparable vulgarity, these Jewish hooligans, some rabbis among them, were elevated to the status of heroes among the Jewish people, especially in Israel.

"This is a critical hour in the history of Israel and the Jewish people. The great problem for Israel is the problem of being powerful." With incredible foresight, the distinguished Jewish leader Nahum Goldmann, who died a month ago, saw this when he said: "For two thousand years we were powerless as a people, and without power we learned how to be the best visionaries, the best dreamers, the best idealists. But without power we could not implement our visions. Now the powerless have become powerful. We have an army and flags and a state and victories, and in America Jews are well organized and wealthy, but we have not yet learned how to use our power in the service of our visions. To place our reliance on power is our greatest weakness. The survival of the Jewish people is more in danger today than ever before. There can be no survival without peace."

This is a critical hour in the history of Israel and the Jewish people-There can be no survival without peace, peace between the great powers, peace between Israel and her rejecting Arab neighbors. And this, it seems to me, is where we enter the picture. For if this is a critical hour, it is also an hour full of promise if it brings us to contrition, to some humility, some acknowledgment of our own culpability.

It is easy to find culprits: Get the rascals out! That is the language of politics. Contrition is not the American style; finding culprits is. But contrition is the purpose of this Holyday, of Yom Kippur. It is our weapons that have killed all of the combatants in this futile war, those massacred by the Christian Phalangists at the Shatila Camp in Beirut-our American-made aircraft bombed the cities of Lebanon; even the PLO had American weapons courtesy of one of our major allies, Saudi Arabia; weapons provided by every American government, Democratic and Republican.

It is the great powers, we and the Soviet Union, who have set the pattern to be emulated by the rest of the world. When faced by an adversary one must be willing to sacrifice everything in the search for military superiority. The great powers have declared their willingness to destroy life everywhere on this earth, if need be. The race to nuclear armaments does not provide security; it poisons the total atmosphere of human discourse and aspiration; it provides the moral context for the violence taken up by the tiny nations of the world.

The nuclear technicians in the highest offices who conceive and prepare for limited or protracted nuclear wars with acceptable risks of millions upon millions of casualties, all the makers of those sadistic scenarios, are they not the real assassins? We cannot remain silent as those assassins go about their grizzly work of preparation, any more than we would have wanted those Israeli soldiers and their commanders to have been silent as the Christian Phalangists prepared and then executed their massacre in the Shatila refugee camp.

The possession of nuclear weapons and the very planning of their use is an offense against God and against humanity, against all that is holy in Judaism. This 
is not a time to be silent; we must join the peacemakers. And we have a modest but most significant opportunity to send a stirring and vital message to our own government and to the Soviet Union through Proposition 12 on our November ballots - the call for a Bilateral Nuclear Weapons Freeze. This is a time not only to vote ourselves, but also to encourage others to do so. We cannot permit ourselves any longer to succumb to the crime of silence, for we are responsible for everything against which we do not protest.

Our country is not at the center of the planet; nor is the Soviet Union. This is not the American Century nor the Russian Century. This is the human century, and the first order of human business, as my friend William Sloane Coffin has said, is to freeze nuclear weapons before we are all burned by them.

Yes, time to confess our own culpability at this judgment season. Let us confess that we, and the leaders of the Jewish community and all of their agencies, have neglected our moral tasks by failing to protest each step that led Israel deeper and deeper into the whirlpool of Lebanese hatreds.

Let us confess that by adhering to the view that American Jews should not oppose decisions of the Israeli government, we emboldened those who see enmity and endless militancy as the only future, and we failed to encourage those in Israel who saw more clearly that this was a moral tragedy, an insult to the noblest impulses of our Jewish heritage.

This is a time then for a clear declaration from us, a declaration of independence. We will not abdicate our conscience to anyone. We will not abdicate our conscience to the decisions of our own government or to any Israeli government or to any Jewish organization. We will demand a full and open accounting. We will insist on the presentation of options, a debate of alternatives.

Let us resolve to begin our repentance by a renewed commitment to Israel and the Jewish people by urging Israel to renew the search for peace, accepting the American initiative as a start for serious negotiations that could both lead to a resolution of the issues of Israeli security and Palestinian homelessness, and help to bring the tragic cycle of death and destruction to an end. At this judgment season, this time of the affliction of our souls, for the love of our people we can do no less. "For Zion's sake, we may no longer keep silent; for Jerusalem's sake, we may not be still."

"Everything on this earth follows the age-old rules" ... must it be so? "The world is a dark pit and men stumble and falter; they aim for the good and commit the evil... they are full of errors and full of lies, and everything has its reason and its cause ... Yet I pray for a miracle, many miracles, a rain, a storm of miracles that will sweep down over mankind. May at last the evil one's hand, as he lifts it to beat another, be paralyzed. May at last the man who opens his mouth to speak an evil word ... may he be stricken with silence ... I am so tired of the age-old rules and laws."

What does it all mean? What is it we want, my friends? What is it do you suppose that every person yearns for: Jew, non-Jew, American, Russian, Chinese, 
Lebanese, Israeli, Palestinian? Only this, I believe, something stated poignantly by Lillian Hellman:

"It no longer matters whose fault it is. It matters that this game be stopped . . . We want to declare that there are still men and women in the world who do not think it is dangerous or radical to declare themselves for the continuation of life... we place ourselves among those who wish to live, think, and breathe, to eat and play and raise their children, among the millions who want to be a little use, and have a little pleasure, and bear a little sorrow, and die a little death, close to someone who has loved them, in decency and in peace."

(For some of the above thoughts on Israel, I am indebted to my Israeli friends Simha Flapan and David Shaham.)

\section{COMMENTARY BY CONNIE BRUCK}

I did not know Leonard until many years after he delivered this sermon, in 1982. Reading it, though, I see hallmarks of the Yom Kippur sermons I treasured, in the last decade of his life. He often began with self-deprecating humor, and an acknowledgement that he knew some congregants would much prefer not to hear what he was about to say. He would try hard to reach them, though, with his warmth, empathy, eloquence, and inspired allusions to literature and to Jewish teachings. He would often speak about Israelis who opposed their government's policy toward the Palestinians - thus demonstrating that what was almost taboo in the organized Jewish world, here, was frequently expressed, there. As he recounted in this sermon, being the rabbi of a congregation "as fashionable and respectable as this one" was inherently challenging, for he was "the bearer of a religious tradition whose God pants after the disinherited, the lonely, the abandoned, the homeless."

Despite that challenge, Leonard never tailored his message. In his sermons, he may have started off disarmingly, but he built his argument steadily, meticulously, and inexorably, until he had earned the right to articulate what he fully believed. When he delivered this sermon, the massacre at Sabra and Shatila had taken place just ten days earlier. He had opposed the Lebanon War from the start, though he said he had prayed his fears would prove unfounded. Now, he excoriated Menachem Begin and Ariel Sharon for their actions; later investigations showed how right Leonard was. As he said of that war, "What kinds of Jews are these who kill and injure so many thousands and cause such massive destruction as a reasonable technique for carrying out policy?" But he found some solace in the fact that "thousands upon thousands of Israeli citizens (over 300,000 of them) and Jews throughout the world are expressing their shock and shame-a tribute to the true Jewish spirit, a clear demonstration that it still breathes." Tragically for the Israel Leonard loved, he was far-sighted not only about the Lebanon War but about so much else that the government of Israel has undertaken. 